\title{
Pengaruh Layanan Rehabilitasi Narkotika terhadap Kualitas Hidup Warga Binaan Pemasyarakatan di Lembaga Pemasyarakatan
}

\author{
Putri Herdriani*, Palupi Lindiasari Samputra \\ Program Kajian Ketahanan Nasional, Universitas Indonesia, Jakarta \\ *Correspondence email: putri.herdriani@ui.ac.id, palupi.ls@ui.ac.id
}

\begin{abstract}
Abstrak. Lembaga pemasyarakatan merupakan salah satu lembaga yang menyelenggarakan layanan rehabilitasi narkotika, yang tertuang dalam Peraturan Menteri Hukum dan Ham Nomor 12 Tahun 2017 tentang Penyelenggaraan Layanan Rehabilitasi Narkotika bagi Tahanan dan Warga Binaan Pemasyarakatan (WBP). Penelitian ini bertujuanuntuk menganalisis pengaruh layanan rehabilitasi terhadap kualitas hidup warga binaan pemasyarakatan di Lapas Narkotika Klas II A Jakata.Peneliti menggunakan pendekatan kuantitatif menggunakan kuesioner WHOQOL-BREF dengan jumlah data sekunder sebanyak 493 WBP. Teknik analisis data menggunakan analisis faktor dan regresi linear berganda. Peneliti juga melakukan wawancara kepada 2 orang WBP untuk melihat gambaran layanan rehabilitasi yang dapat mempengaruhi kualitas hidup. Hasil penelitian terdapat pengaruh signifikan dan positif antara kesehatan psikologis dengan kualitas hidupsebesar 0.085 , hubungan sosial dengan kualitas hidup sebesar 0.114, dan terdapat pengaruh signifikan positif antara Kesehatan fisik terhadap kualitas hidup sebesar 0,045. Sedangkan variabel hubungan lingkungan tidak mempengaruhi kualitas hidup secara statistik. Terdapat pengaruh signifikan secara simultan dari empat variable tersebut terhadap kualitas hidup WBP yang mengikuti layanan rehabilitasi di Lapas Narkotika Klas II A Jakarta.
\end{abstract}

Kata Kunci: rehabilitasi narkotika; kualitas hidup; warga binaan pemasyarakatan; WHOQOL-BREF

Abstract. The correctional institution is one of the institutions that provide narcotics rehabilitation services, stipulated in the Regulation of the Minister of Law and Human Rights Number 12 of 2017 concerning the Implementation of Narcotics Rehabilitation Services for Prisoners and Correctional Assistants (WBP). This study aims to analyze the effect of rehabilitation services on prisoners' quality of life in prison at Class II A Narcotics Prison, Jakarta. Researchers used a quantitative approach using the WHOQOL-BREF questionnaire with a total of 493 WBP of secondary data. The data analysis technique used factor analysis and multiple linear regression. The researcher also conducted interviews with two prisoners to see an overview of rehabilitation services that could affect life quality. The results showed a significant and positive influence between psychological health and quality of life of 0.085 , social relations with quality of life of 0.114 , and a significant favorable influence between physical health and quality of life of 0.045. Meanwhile, the environmental relationship variable does not statistically affect the quality of life. There is a significant simultaneous effect of these four variables on prisoners' quality of life who participate in rehabilitation services at the Class II-A Narcotics Prison, Jakarta.

Keywords: narcotics rehabilitation; quality of life; prisoners; WHOQOL-BREF

\section{PENDAHULUAN}

Paradigma global mengenai pecandu, penyalahguna dan korban penyalahguna narkotika dalam perkembangannya telah berubah, mereka tidak lagi diartikan sebagai pelaku kriminal melainkan sebagai orang yang menderita penyakit kecanduan (adiksi) sehingga perlu dilakukan rehabilitasi. Paradigma ini semakin kuat mempengaruhi negara - negara di dunia, terutama bagi yang tergabung dalam World Health Organization (WHO) termasuk Indonesia, semua mengikuti perubahan pandangan internasional tersebut. Di Indonesia melalui Undang-Undang RI Nomor 35 tahun 2009 tentang Narkotika, tindakan bagi pelaku, produsen, impor dan ekspor ilegal, serta peredaran gelap narkotika adalah dengan hukuman berat, namun sangat humanis terhadap para pecandu, penyalahguna dan korban penyalahgunaan narkotika.

Narkotika sebagai zat yang berasal dari tanaman atau bukan tanaman, baik sintetis maupun semi sintetis dapat menyebabkan penurunan atau perubahan kesadaran diri dan juga ketergantungan. Ketergantungan narkotika pada umumnya disebabkan oleh beberapa faktor yaitu, sifat dari zat yang terkandung di dalam narkotika, faktor individu dan lingkungan. Pecandu atau penyalahguna narkotika seringkali stres dan berpikiran negatif karena tertekan oleh apa yang sedang dihadapinya sehingga sulit untuk mencapai kepulihan. Unsur - unsur tersebut itulah yang membuat narkotika menjadi barang yang sangat dilarang untuk disalahgunakan dan diedarkan.

Meningkatnya kasus tindak pidana dan penyalahgunaan narkotika di lembaga pemasyarakatan tidak terlepas dari persoalan permintaan (demand) dan ketersediaan pasokan (supply) narkotika secara agresif dan terus menerus yang terjadi di lingkungan masyarakat umum (BNN, 2017). Selain itu selalu ada cara baru dalam peredarannya begitu juga dengan jenis zat barunya. Jumlah tahanan dan warga binaan pemasyarakatan (WBP) kasus narkotika sebagai pengguna mengalami peningkatan, yaitu pada tahun 
2014 sebesar 28.609 lalu pada tahun 2018 menjadi sebesar 41.979 (Direktorat Perawatan Kesehatan dan Rehabilitasi Kemenkumham, 2018).Sedangkan pada tahun 2019 jumlahnya juga mengalami kenaikan yang cukup tinggi, yaitu sebesar 49.983 (Ditjenpas, 2020).

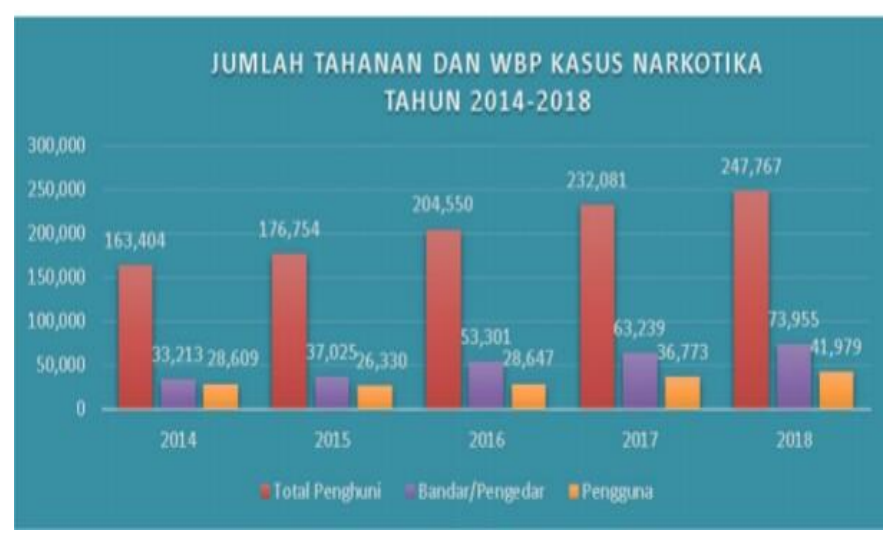

Gambar 1. Grafik Jumlah Tahanan dan WBP Kasus Narkotika Tahun 2014-2018

*)Sumber : Direktorat Perawatan Kesehatan dan Rehabilitasi Kemenkumham, 2018

Untuk kondisi tersebut pada tahun 2017 Kementerian Hukum dan HAM RI khususnya Direktorat Jenderal Pemasyarakatan telah mengambil langkah langkah strategis dalam rangka memberikan pelayanan dan penanganan terhadap warga binaan pemasyarakatan kasus narkotika yang secara spesifik memiliki kekhususan dalam pembinaannya, yaitu melalui rehabilitasi. Hal tersebut tertuang dalam Permenkumham Nomor 12 Tahun 2017 tentang Penyelenggaraan Layanan Rehabilitasi Narkotika bagi Tahanan dan Warga Binaan Pemasyarakatan. Dalam Permenkumham ini tertuang tujuannya adalah memberikan pelayanan dan jaminan perlindungan terhadap hak tahanan dan warga binaan pemasyarakatan, diantaranya memulihkan dan mempertahankan kondisi kesehatan dari aspek biologis, psikologis dan sosial dari ketergantungan terhadap Narkotika, psikotropika dan zat adiktif lainnya serta meningkatkan produktivitas serta kualitas hidup tahanan dan WBP sehingga mampu menjalankan fungsi sosial ketika kembali ke masyarakat.

Rehabilitasi merupakan salah satu solusi yang tepat untuk para pecandu melepaskan diri dari jeratan narkotika. Lembaga pemasyarakatan merupakan salah satu lembaga yang menyelenggarakan rehabilitasi narkotika kepada para warga binaannya. Para WBP yang telah menjalani rehabilitasi di lapas diharapkan menjadi individu yang memiliki ketahanan diri ketika sudah kembali ke masyarakat (berfungsi sosial), penyalahgunaan narkotika merupakan ancaman terhadap ketahanan nasional apabila terus berkembang dan semakin sulit dikendalikan dimana target utamanya adalah individu yang merupakan aktor utama dalam menjalankan kehidupan bernegara dalam mencapai tujuan nasional.
Lembaga Pemasyarakatan Narkotika Kelas II A Jakarta merupakan salah satu lembaga pemasyarakatan khusus narkotika yang melaksanakan layanan rehabilitasi narkotika dalam bentuk pembinaan terapi rehabilitasi medis, sosial, dan pascarehabilitasi (Kemenkumham, 2017). Lapas Narkotika Klas II A Jakarta melaksanakan program rehabilitasi narkotika sejak tahun 2013 dan merupakan salah satu lapas yang memiliki sarana prasarana cukup baik dan petugas yang telah memiliki kompetensi dalam layanan rehabilitasi. Namun dalam pelaksanaan layanan rehabilitasi di Lapas Narkotika Kelas II A Jakarta selama ini belum pernah dilakukan evaluasi sehingga belum dapat diketahui efektivitas layanan rehabilitasinya.

Salah satu cara untuk melihat efektivitas layanan rehabilitasi yang telah diberikan kepada warga binaan pemasyarakatan tersebut adalah dengan mengetahui kualitas hidupnya. Hal tersebut sesuai dengan salah satu tujuan diselenggarakannya layanan rehabilitasi narkotika kepada WBP di Lembaga Pemasyarakatan Narkotika Kelas II A Jakarta yaitu, meningkatkan produktivitas dan kualitas hidup WBP agar dapat menjalankan fungsi sosialnya dilingkungan masyarakat, berperan aktif dalam pembangunan serta dapat hidup secara wajar sebagai warga yang baik dan bertanggung jawab setelah keluar dari lembaga pemasyarakatan (Kemenkumham, 2017). Alasan pemilihan Lapas Narkotika Kelas II A Jakarta adalah karena lapas tersebut merupakan lapas yang warga binaannya merupakan para narapidana dengan kasus narkotika serta merupakan lapas percontohan.

Selain itu hal tersebut juga sejalan dengan penelitian yang dilakuan oleh Anggarwati dan Nawangsih bahwa pemberian layanan komprehensif (rehabilitasi) akan mengembangkan pribadi klien dan mampu memperoleh kesejahteraan fisik, emosional dan sosial sesuai dengan kemampuan dalam dirinya karena merupakan personal values and aspiration dalam membentuk kualitas hidup (Anggarwati \& Nawangsih, 2016). Selanjutnya Ayu mengemukakan kualitas hidup bagi para penguna narkotika seharusnya menjadi perhatian penting bagi para profesional kesehatan karena dapat menjadi acuan keberhasilan dari suatu tindakan, intervensi, atau terapi, selain itu data tentang kualitas hidup juga dapat merupakan data awal pertimbangan merumuskan intervensi atau tindakan yang tepat bagi pasien (Anggarwati \& Nawangsih, 2016). Lalu Pasareanu et. al. juga mengemukakan kualitas hidup meningkat pada tindak lanjut perawatan gangguan penggunaan zat rawat inap (Pasareanu et al., 2015). Dalam penelitiannya bahwa pengobatan gangguan penggunaan zat pada rawat inap meningkatkan kualitas hidup pada enam bulan masa tindak lanjut. Temuan ini menunjukkan bahwa pengukuran kualitas hidup berguna untuk memberikan bukti manfaat terapeutik di bidang SUD (gangguan penggunaan zat).

Penelitian lain menyebutkan kualitas hidup mantan pecandu narkoba di klinik rehabilitasi Badan 
Narkotika Nasional (BNN) kota Kendari, bahwa mantan pecandu narkoba mampu menjalankan aktivitasnya seperti biasa tanpa merasa capek dan kelelahan yang berlebihan (Prasetya, Aynal Mardiyah La Dupai, 2018). Perasaan positif yang dirasakan mantan pecandu narkoba antara lain perasaan sabar, optimis, semangat. Sedangkan perasaan negatif yang dirasakan meliputi rasa malu, menyesal serta hasrat terkadang timbul untuk menggunakan narkoba kembali.

Rehabilitasi narkoba menurut David Arnot adalah suatu proses pemulihan seseorang dari gangguan kecanduan narkoba, pemulihan ini dapat bersifat jangka pendek maupun panjang (Wijayanti, 2019). Rehabilitasi juga merupakan proses pemulihan pada ketergantungan penyalahgunaan narkoba secara komprehensif, meliputi aspek biopsikososial dan spiritual sehingga memerlukan jangka waktu lama, kemauan yang keras, kesabaran, konsistensi, serta pembelajaran yang terus-menerus. Yang berarti klien perlu memiliki kesadaran untuk berubah dan dapat membangun kualitas hidup yang lebih baik.

Rehabilitasi narkotika di lembaga pemasyarakatan merupakan layanan yang ditujukan bagi WBP dalam kategori pecandu, penyalahguna dan korban penyalahgunaan narkotika, berdasarkan hasil skrining dan asesmen. Rehabilitasi narkotika bagi WBP dilaksanakan melalui beberapa tahapan, yaitu:

1. Informasi awal, diberikan informasi mengenai penyalahgunaan narkotika dan layanan rehabilitasi yang tersedia. Informasi awal ini diberikan pada proses mapenaling (masa pengenalan lingkungan) dan satu paket dengan informasi kesehatan dasar lainnya

2. Skrining mengetahui dan mengidentifikasi jenis zat yang digunakan serta tingkat risiko penyalahgunaan narkotika.

3. Asesmen rehabilitasi, pengumpulan informasi untuk mendapatkan gambaran klinis dan masalah yang lebih mendalam dari Tahanan dan WBP secara komprehensif, baik pada saat memulai, selama menjalani, hingga selesai mengikuti layanan rehabilitasi.

4. Rehabilitasi medis dan Sosial, bertujuan untuk abstinesia atau penghentian total penggunaan zat, pengurangan frekuensi dan keparahan relaps, memperbaiki fungsi fisik, psikologi dan fungsi adaptasi sosial.

5. Persiapan Pascarehabilitasi, rekomendasi jenis layanan pascarehabilitasi, re-asesmen di lakukan dengan wawancara mendalam, hasil minat dan bakat, pemeriksaan psikologi (Ditjenpas, 2018).

Layanan rehabilitasi narkotika mencakup layanan rehabilitasi medis dan sosial, durasi layanan selama 6 bulan. Layanan rehabilitasi sosial menggunakan metode atau program terapi komunitas/ TC (Therapeutic Community) yang dimodifikasi berdasarkan kebutuhan, terdiri dari kegiatan evaluasi fisik dan psikis yang dilaksanakan selama 2 minggu. Lalu program inti dilaksanakan selama 19 minggu dengan fokus kegiatan pada perubahan perilaku serta kegiatan persiapan pasca rehabilitasi yang dilaksanakan selama 3 minggu. Dalam melaksanakan layanan rehabilitasi terdapat tiga aspek yang harus dipenuhi yaitu petugas layanan, program yang diberikan dan sarana prasarana yang mendukung kegiatan.

Organisasi kesehatan dunia (WHO) mendefinisikan kualitas hidup sebagai persepsi individu dari posisi mereka dalam kehidupan, dalam konteks sistem budaya dan nilai dimana mereka hidup dan dalam hubungannya dengan tujuan mereka, harapan, standar, dan kekhawatiran. Pengertian tersebut memiliki pandangan yang luas mengenai kesehatan mental seseorang, baik kesehatan fisik, keadaan psikologis, tingkat kemandirian, hubungan sosial, keyakinan pribadi, dan hubungan mereka dengan fitur-fitur yang menonjol dilingkungan mereka (Janca, 1998). Untuk melihat kualitas hidup warga binaan pemasyarakatan tersebut mengacu pada WHOQOL-BREF terdiri dari 24 facets(aspek) yang mencakup 4 domain dan terbukti dapat mengukur kualitas hidup seseorang, yaitu (Laratmase, 2016):

1. Kesehatan fisik, terdiri dari tujuh aspek : aktivitas sehari-hari, ketergantungan pada bahan-bahan medis atau pertolongan medis, tenaga dan kelelahan, mobilitas, rasa sakit dan ketidaknyamanan, tidur dan istirahat, serta kapasitas bekerja.

2. Kesehatan Psikologis, terdiri dari enam aspek : body image dan penampilan, perasaan-perasaan negatif dan positif, kepercayaan personal, pikiran, belajar, memori dan kosentrasi.

3. Hubungan Sosial, terdiri dari tiga aspek : hubungan personal, dukungan sosial dan aktivitas seksual.

4. Hubungan dengan Lingkungan, terdiri dari delapan aspek : sumber-sumber finansial, kebebasan, keamanan dan keselamatan fisik, perawatan kesehatan dan sosial (aksesibilitas dan kualitas), lingkungan rumah, kesempatan untuk memperoleh informasi dan belajar keterampilan baru, kesempatan untuk rekreasi atau memiliki waktu luang, lingkungan fisik.

Selanjutnya pada penelitian sebelumnya belum ada yang meneliti tentang kualitas hidup WBP yang secara spesifik mengikuti layanan rehabilitasi narkotika di lapas. Oleh karena itu maka perlu dilakukan penelitian ini yang bersifat evaluasi terhadap penyelenggaraan layanan rehabilitasi narkotika di lembaga pemasyarakatan dan menilai pengaruhlayanan rehabilitasi terhadap kualitas hidup warga binaan pemasyarakatan di Lapas Narkotika Klas II A Jakata.Kemudianpenelitian ini dimaksudkan agar menjadi dasar atau referensi baik dalam evaluasi penyelenggaraan rehabilitasi di lembaga pemasyarakatan 
di Lapas Narkotika Klas II A Jakarta maupun dalam merencanakan program - program dan kebijakan selanjutnya sebagai upaya memberikan layanan yang sesuai dengan kebutuhan warga binaan pemasyarakatan.

\section{METODE}

Penelitian dalam jurnal ini menggunakan pendekatan kuantitatif. Terdapat dua variabel yang digunakan, variabel dependen adalah kualitas hidup warga binaan Lapas Narkotika Klas II A Jakarta, sedangkan variabel independen yaitu kesehatan fisik, kesehatan psikologis, hubungan sosial dan hubungan dengan lingkungan. Peneliti menggunakan data sekunder berupa kuesioner WHOQOL-BREF yang telah diisi oleh 493 WBP Lapas Narkotika Klas II A Jakarta yang merupakan seluruh peserta rehabilitasi pada gelombang ke 2 (dua) di tahun 2020, dimana dilakukan uji validitas terlebih dahulu sebelum melakukan analisis. Peneliti juga melakukan wawancara kepada 2 orang WBP untuk melihat gambaran layanan rehabilitasi yang dapat mempengaruhi kualitas hidup.
Teknik analisis data penelitian menggunakan metode analisis faktor dan regresi linier berganda. Analisis faktor digunakan untuk menganalisis adanya faktor - faktoryang dapat mempengaruhi kualitas hidup WBP. Sedangkan untuk metode analisis regresi linier berganda digunakan untuk menganalisis adanya pengaruh kesehatan fisik, kesehatan psikologis, hubungan sosial dan hubungan dengan lingkungan terhadap kualitas hidup Warga Binaan Pemasyarakatan (WBP) di Lapas Narkotika Klas II A Jakarta.

\section{HASIL DAN PEMBAHASAN}

Pada bagian ini akan dipaparkan hasil analisis data terkait kualitas hidup danpengaruh layanan rehabilitasi terhadap kualitas hidup WBP Lapas Narkotika Klas II A Jakarta. Sebelum dilakukan analisis data, peneliti melakukan uji validitas dan reliabilitas terhadap kuesioner WHOQOL-BREF. Hasil uji tersebut terlihat pada Tabel 1.

Tabel 1. Hasil Deskriptif dan Uji Validitas, Reliabilitas dan Kecukupan Data

\begin{tabular}{|c|c|c|c|c|c|c|}
\hline Item & Mean & $\begin{array}{l}\text { Corrected Item- } \\
\text { Total Correlation }\end{array}$ & $\begin{array}{l}\text { Cronbach's Alpha if } \\
\text { Item Deleted }\end{array}$ & $\begin{array}{l}\text { Anti-Image } \\
\text { Correlation }\end{array}$ & $\begin{array}{c}\text { Cronbach's } \\
\text { Alpha }\end{array}$ & $\begin{array}{l}\text { KMO dan } \\
\text { Bartlett's }\end{array}$ \\
\hline \multicolumn{6}{|c|}{ Variabel Independen } & \multirow{25}{*}{$\begin{array}{c}0,905 \\
(0,000)\end{array}$} \\
\hline KF1 & 3.908 & 0.185 & 0.896 & 0.960 & \multirow{24}{*}{0,894} & \\
\hline $\mathrm{KF} 2$ & 4.217 & 0.182 & 0.897 & 0.746 & & \\
\hline KF3 & 3.697 & 0.549 & 0.888 & 0.930 & & \\
\hline KF4 & 3.933 & 0.426 & 0.891 & 0.907 & & \\
\hline KF5 & 3.519 & 0.608 & 0.887 & 0.934 & & \\
\hline KF6 & 3.541 & 0.601 & 0.888 & 0.916 & & \\
\hline KF7 & 3.036 & 0.608 & 0.887 & 0.938 & & \\
\hline KP1 & 3.202 & 0.548 & 0.888 & 0.883 & & \\
\hline KP2 & 3.750 & 0.562 & 0.888 & 0.891 & & \\
\hline KP3 & 2.415 & 0.541 & 0.889 & 0.917 & & \\
\hline KP4 & 2.720 & 0.575 & 0.888 & 0.951 & & \\
\hline KP5 & 2.237 & 0.628 & 0.887 & 0.925 & & \\
\hline KP6 & 3.941 & 0.243 & 0.895 & 0.865 & & \\
\hline HS1 & 3.452 & 0.608 & 0.888 & 0.959 & & \\
\hline HS2 & 3.434 & 0.376 & 0.893 & 0.841 & & \\
\hline HS3 & 3.409 & 0.562 & 0.888 & 0.929 & & \\
\hline HL1 & 3.750 & 0.577 & 0.888 & 0.921 & & \\
\hline HL2 & 3.492 & 0.531 & 0.889 & 0.918 & & \\
\hline HL3 & 2.405 & 0.413 & 0.892 & 0.891 & & \\
\hline HL4 & 3.381 & 0.486 & 0.890 & 0.926 & & \\
\hline HL5 & 2.793 & 0.458 & 0.891 & 0.873 & & \\
\hline HL6 & 2.910 & 0.457 & 0.891 & 0.907 & & \\
\hline HL7 & 2.348 & 0.475 & 0.890 & 0.876 & & \\
\hline HL8 & 3.815 & 0.436 & 0.891 & 0.861 & & \\
\hline
\end{tabular}

Nilai uji Cronbach's Alpha yang diinginkan adalah $>0,7$. Terlihat pada tabel 1 nilai yang didapatkan adalah 0,894 sehingga kuesioner memenuhi syarat reliabilitas. Sedangkan nilai uji validitas nilai yang dinginkan adalah $>0,088$, pada tabel 1kolom Corrected Item-Total Correlation didapatkan nilai setiap item pernyataan $>0,088$. Hasil tersebut menunjukan bahwa tiap item pernyataan adalah valid, sehingga analisis data dapat dilanjutkan.

Setelah dilakukan uji validitas dan reliabilitas, langkah selanjutnya adalah melakukan analisis faktor terhadap 24 item kuisioner. Berdasarkan hasil analisis factor pada tabel 1 didapatkan nilai KMO dan Bartlett sebesar 0,905 dengan signifikansi 0,000. Nilai tersebut menunjukkan bahwa variabel and sampel 
memungkinkan untuk dilakukan uji atau analisis lebih lanjut. Hal itu sesuai dengan persyaratan nilai KMO and Bartlett yang ditetapkan adalah $>0,5$. Selanjutnya, untuk melihat adanya korelasi atau hubungan antar variabel independen dapat dilihat pada tabel 1 kolom Anti Image Correlation. Nilai MSA (Measure of Sampling Adequacy) dalam penelitian ini lebih dari 0.5. Maka seluruh variabel independen dapat dianalisis lebih lanjut.

Tabel 2. Hasil Analisis Faktor

\begin{tabular}{|c|c|c|c|c|}
\hline & Factor & $\begin{array}{c}\text { Initial Eigen } \\
\text { Values }\end{array}$ & $\begin{array}{c}\% \text { of } \\
\text { Variance }\end{array}$ & $\begin{array}{c}\text { Loading } \\
\text { Factor }\end{array}$ \\
\hline Fakto & I (Hubungan dengan lingkungan) & 7,448 & 31,033 & \\
\hline Q25 & Seberapa jauh ketersediaan informasi bagi kehidupan Anda dari hari ke hari? & & & 0,767 \\
\hline Q14 & $\begin{array}{l}\text { Seberapa sering Anda memiliki kesempatan untuk bersenang-senang / } \\
\text { rekreasi? }\end{array}$ & & & 0,720 \\
\hline Q24 & Seberapa puaskah Anda dengan akses Anda pada layanan kesehatan? & & & 0,621 \\
\hline Q21 & Seberapa puaskah Anda dengan kehidupan seksual Anda? & & & 0,596 \\
\hline Q9 & $\begin{array}{l}\text { Seberapa sehat lingkungan dimana Anda tinggal (berkaitan dengan sarana dan } \\
\text { prasarana)? }\end{array}$ & & & 0,584 \\
\hline Q13 & Seberapa jauh ketersediaan informasi bagi kehidupan Anda dari hari ke hari? & & & 0,570 \\
\hline Q23 & Seberapa puaskah Anda dengan kondisi tempat Anda tinggal saat ini? & & & 0,566 \\
\hline Q16 & Seberapa puas Anda dengan tidur Anda? & & & 0,498 \\
\hline Fakto & 2 (Kesehatan psikologis) & 2,767 & 11,528 & \\
\hline Q8 & $\begin{array}{l}\text { Secara umum, seberapa aman Anda rasakan dalam kehidupan Anda sehari- } \\
\text { hari? }\end{array}$ & & & 0,753 \\
\hline Q6 & Seberapa jauh Anda merasa hidup Anda berarti? & & & 0,700 \\
\hline Q7 & Seberapa jauh Anda mampu berkonsentrasi? & & & 0,699 \\
\hline Q5 & Seberapa jauh Anda menikmati hidup Anda? & & & 0,697 \\
\hline Q11 & Apakah Anda dapat menerima penampilan tubuh Anda? & & & 0,680 \\
\hline Q12 & Apakah Anda memiliki cukup uang untuk memenuhi kebutuhan Anda? & & & 0,588 \\
\hline Q10 & Apakah Anda memiliki vitalitas yang cukup untuk beraktivitas sehari-hari? & & & 0,576 \\
\hline Q17 & $\begin{array}{l}\text { Seberapa puas Anda dengan kemampuan Anda untuk menampilkan aktivitas } \\
\text { kehidupan Anda sehari-hari? }\end{array}$ & & & 0,436 \\
\hline Fakto & 3 (Hubungan dengan social) & 1,459 & 6,081 & \\
\hline Q22 & $\begin{array}{l}\text { Seberapa puaskah Anda dengan dukungan yang Anda peroleh dari teman } \\
\text { Anda? }\end{array}$ & & & 0,680 \\
\hline Q15 & Seberapa baik kemampuan Anda dalam bergaul? & & & 0,674 \\
\hline Q19 & Seberapa puaskah Anda terhadap diri Anda? & & & 0,650 \\
\hline Q18 & Seberapa puaskah Anda dengan kemampuan Anda untuk bekerja? & & & 0,507 \\
\hline Q20 & Seberapa puaskah Anda dengan hubungan personal/sosial Anda? & & & 0,494 \\
\hline Fakto & 4 (Kesehatan fisik) & 1,272 & 5,301 & \\
\hline Q3 & $\begin{array}{l}\text { Seberapa jauh rasa sakit fisik Anda mencegah Anda dalam beraktivitas sesuai } \\
\text { kebutuhan Anda? }\end{array}$ & & & 0,819 \\
\hline Q4 & $\begin{array}{l}\text { Seberapa sering Anda membutuhkan terapi medis untuk dapat berfungsi } \\
\text { dalam kehidupan sehari-hari Anda? }\end{array}$ & & & 0,729 \\
\hline Q26 & $\begin{array}{l}\text { Seberapa sering Anda memiliki perasaan negatif seperti feeling blue } \\
\text { (kesepian), putus asa, cemas dan depresi? }\end{array}$ & & & 0,632 \\
\hline
\end{tabular}

Tahap selanjutnya adalah melihat berapa faktor yang terbentuk, yaitu dari tabel 2 didapatkan adanya 4 faktor atau komponen yang terbentuk. Syarat nilai eigen yang ditetapkan adalah diatas angka 1 (satu). Berdasarkan tabel 2 didapatkan faktor 1 (hubungan dengan lingkungan) mampu menjelaskan sebesar 31,033 persen, faktor 2 (kesehatan psikologis) sebesar 11,528 persen, faktor 3 (hubungan dengan social) sebesar 6,081 persen, factor 4 (kesehatan fisik) sebesar 5,301 persen.Faktor hubungan dengan lingkungan dijelaskan oleh indikator "Jarak ketersediaan informasi bagi kehidupan sehari-hari" dengan nilai LF tertinggi 0,767.Faktor psikologis dijelaskan oleh indikator perasaan aman dalam kehidupan sehari-hari, dengan nilai LF tertinggi 0,753. Faktor selanjutnya yakni hubungan dengan social dijelaskan oleh kepuasan atas dukungan dari teman, dengan nilai LF sebesar 0,680. Terakhir, factor fisik dijelaskan oleh indikator rasa sakit fisik yang mencegah dalam beraktivitas, dengan nilai LF sebesar 0,819 .

Tahap berikutnya adalah analisis regresi berganda antara variabel hubungan dengan lingkungan, kesehatan psikologis, hubungan sosial dan kesehatan fisik terhadap variabel kualitas hidup dengan menggunakan SPSS 23. Dan didapatkan data sebagai berikut: 
Putri Herdriani dan Palupi Lindiasari Samputra, Pengaruh Layanan Rehabilitasi Narkotika terhadap Kualitas Hidup Warga Binaan Pemasyarakatan Di Lembaga Pemasyarakatan

Tabel 3. Hasil Analisis Regresi Pengaruh Layanan Rehabilitasi terhadap Kualitas Hidup

\begin{tabular}{lccccccc}
\hline & $\mathbf{B}$ & Std Deviasi & $\mathbf{F}$ & $\mathbf{T}$ & $\mathbf{R}$ Square & VIF & Sig. \\
\hline Constant & & & 72,669 & & 573 & & \\
Hubungan Lingkungan & 0.153 & 0,374 & & 5,757 & & 1,499 & 0,296 \\
Kesehatan Psikologis & 0.085 & 0,011 & & 1,046 & & 2,011 & 0,000 \\
Hubungan Sosial & 0.114 & 0,013 & & 6,772 & & 2,011 & 0,000 \\
Kesehatan Fisik & 0.045 & 0,026 & & 5,327 & & 1,109 & 0,079 \\
\hline
\end{tabular}

Berdasarkan tabel diatas didapatkan nilai adjusted R Square (determinasi) sebesar 0,373. Angka tersebut menunjukkan bahwa variable independent (hubungan dengan lingkungan, kesehatan psikologi, hubungan dengan social dan kesehatan fisik) mampu menjelaskan sebesar 37,3 persen terhadap variabel independent (kualitas hidup). Hal ini menunjukkan masih terdapat variable lain sebesar 62,7 persen yang dapat mempengaruhi variable dependen (Y).

Uji t dilakukan untuk melihat apakah masingmasing variable independen (X) yang terdiri dari hubungan dengan lingkungan, kesehatan psikologis, hubungan sosial dan kesehatan fisik berpengaruh terhadap variable dependen (Y) yaitu kualitas hidup. Nilai df adalah 3 (tiga) dan signifikansi 0,025 persen (dua sisi), maka didapatkan nilai t tabel adalah 1,960. Nilai sig variable X1 (hubungan dengan lingkungan) = $0,296>0,05$ dan nilai $t$ hitung $1,046<\mathrm{t}$ tabel 1,960 sehingga dapat disimpulkan bahwa hubungan dengan lingkungan tidak mempengaruhi variable kualitas hidup warga binaan pemasyarakatan di Lapas Narkotika Klas II A Jakarta. Nilai sig variable X2 (kesehatan psikologis) $=0,000<0,05$ dan nilai $\mathrm{t}$ hitung 6,772 $>\mathrm{t}$ tabel 1,960 sehingga dapat disimpulkan bahwa kesehatan psikologis mempengaruhi kualitas hidup warga binaan pemasyarakatan di Lapas Narkotika Klas II A Jakarta. Nilai sig variable X3 (hubungan sosial) $=0,000<0,05$ dan nilai $\mathrm{t}$ hitung 2,011 > t tabel 1,960 sehingga dapat disimpulkan bahwa hubungan sosial mempengaruhi kualitas hidup warga binaan pemasyarakatan di Lapas Narkotika Klas II A Jakarta. Nilai sig variable X4 $($ kesehatan fisik $)=0,079>0,05$ dan nilai t hitung 1,760 $<\mathrm{t}$ tabel 1,960 sehingga dapat disimpulkan bahwa kesehatan fisik tidak mempengaruhi variable kualitas hidup warga binaan pemasyarakatan di Lapas Narkotika Klas II A Jakata. Namun pada level tingkat kepercayaan $90 \%$, terdapat pengaruh signifikan antara Kesehatan fisik terhadap kualitas hidup warga binaan.

Nilai F hitung adalah sebesar 72,669 dan nilai signifikansi 0,00 dengan probabilitas 0,05 persen. Dengan nilai df1 sebesar 3 (tiga) dan nilai df2 sebesar 489 , maka didapatkan nilai $F$ tabel sebesar 2,62. Nilai $F$ hitung $=72,669>\mathrm{F}$ tabel $=2,62$ menunjukkan bahwa terdapat pengaruh secara stimultan antara hubungan dengan lingkungan, kesehatan psikologis, hubungan sosial dan kesehatan fisik terhadap kualitas hidup warga binaan pemasyarakatan di Lapas Narkotika Klas II A
Jakata. Untuk menetapkan model persamaan regresi yang dapat merepresentasikan model kualitas hidup WBP, maka dilakukan uji asumsi klasik. Uji multikolineritas dilakukan untuk melihat adanya hubungan antar variabel independen. Pada tabel 5 terlihat nilai VIF (Variance Inflation Factor) semua variable kurang dari 10. Maka tidak ada hubungan antar variabel penelitian (tidak ada multikolineritas). Sedangkan untuk uji heretoskedastisitas, pada tabel 5 didapatkan nilai signifikansi hubungan dengan lingkungan sebesar $0,296>0,05$, signifikansi kesehatan psikologis sebesar $0,000<0,05$, signifikansi hubungan sosial sebesar $0,000<0,05$ dan signifikansi kesehatan fisik sebesar 0,079>0,05. Hasil ini menyatakan bahwa data bersifat heterokedastis. Selanjutnya uji normalitas dapat dikatakan terdistribusi normal apabila nilai Asymp. Sig (2 tailed) > 0,05. Dari tabel One-Sample Kolmogorov-Smirnov Test didapatkan data bahwa nilai Asymp. Sig (2 tailed) adalah 0,37, dengan demikian data penelitian berdistribusi normal. Sedangkan untuk uji linearitas, didapatkan nilai F-Linearity lebih kecil dari 0,05 sehingga menunjukkan bahwa tidak terjadi penyimpangan data.

Persamaan regresi antara variable independent dan dependent ada pada persamaan sebagai berikut:

$\mathrm{Y}=2,153+0,012$ (hubungan dengan lingkungan) + 0,085 (kesehatan psikologis) $+0,114$ (hubungan sosial) $+0,045$ (kesehatan fisik)

Maksud dari persamaan regresi di atas adalah bahwa dalam satuan variabel kualitas hidup dipengaruhi oleh variabel hubungan dengan lingkungan sebesar 0,012, variabel kesehatan psikologis sebesar 0,085 , variabel hubungan sosial sebesar 0,114 dan variabel kesehatan fisik sebesar 0,045. Hubungan social berdampak paling besar terhadap kualitas hidup warga binaan pemasyarakatan di Lapas Narkotika Klas II A Jakarta.

Selanjutnya, dampak terbesar kedua adalah kesehatan psikologis mempengaruhi kualitas hidup WBP. Aspek psikologis yaitu terkait dengan keadaan mental individu. Keadaan mental mengarah pada mampu atau tidaknya individu menyesuaikan diri terhadap berbagai tuntutan perkembangan sesuai dengan kemampuannya, baik tuntutan dari dalam diri maupun dari luar dirinya.Power menyebutkan kesejahteraan 
psikologis mencakup body image dan appearance, perasaan positif, perasaan negatif, self esteem, spiritual/agama/keyakinan pribadi, berpikir, belajar, memori dan konsentrasi (Lopez \& C. R. Snyder, 2003)

Selanjutnya kualitas hidup mantan pecandu narkoba yang sedang menjalani rawat jalan di klinik rehabilitasi ditinjau dari dimensi psikologis (perasaan positif dan negatif) adalah perasaan positif meliputi penerimaan diri, rasa optimis dan semangat dalam menjalani rehabilitasi serta perasaan negatif meliputi malu, menyesal dan tidak ingin untuk menggunakan narkoba kembali (Prasetya, Aynal Mardiyah La Dupai, 2018). Hal tersebut juga sesuai dengan hasil wawancara kepada WBP 1 dan 2, bahwa mereka tidak ingin menggunakan narkoba kembali dan merasa yakin bisa berhenti untuk menggunakan narkoba ketika sudah keluar penjara.

Aspek kesehatan psikologis yang mempengaruhi kualitas hidup juga sejalan dengan penelitian yang dilakukan oleh Muller dan Bukten, bahwa ditemukan korelasi yang sangat kuat antara psychological distress dengan kualitas hidup narapidana (Muller \& Bukten, 2019). Hal tersebut diatas juga sejalan dengan wawancara yang dilakukan pada WBP 1 yaitu responden merasa lebih tenang dan tidak mudah emosi seperti sebelumnya. Sedangkan WBP 2 mengatakan lebih mampu untuk mengungkapkan perasaan-perasaan nya kepada orang lain, merasakan suasana kekeluargaan dan secara spiritual lebih dekat dengan Tuhan. Kedua WBP juga merasa yakin hidup nya kelak akan menjadi lebih baik lagi setelah mengikuti program rehabilitasi dilapas.

Hasil regresi berikutnya menunjukkan bahwa hubungan sosial mempengaruhi kualitas hidup WBP yang mengikuti layanan rehabilitasi di lapas. Aspek hubungan sosial yaitu hubungan antara dua individu atau lebih dimana tingkah laku individu tersebut akan saling mempengaruhi, mengubah, atau memperbaiki tingkah laku individu lainnya, hubungan sosial mencakup hubungan pribadi, dukungan sosial, aktivitas seksual (Lopez \& C. R. Snyder, 2003). Beberapa penelitian terdahulu menunjukkan bahwa hubungan sosial mempengaruhi kualitas hidup narapidana didalam lapas. Yulianti mengatakan bahwa pembinaan dan juga teman - teman yang berada dalam lapas membuat subjek menjadi semangat dan optimis dalam mejalani hukuman, hal tersebut menunjukkan kualitas hidup yang baik dirasakan oleh subjek (Yulianti \& Putri, 2015). Selain itu kualitas hidup di lapas sangat bergantung pada interaksi antara staf penjara dan lingkungan (Barquín et al., 2019). Lalu Ginneken et.al mengatakan tahanan mungkin tidak puas dengan kondisi sarana dan prasarana, namun karena mereka diberi kebebasan untuk bergerak, bahkan bisa melakukan pekerjaan diluar tahanan, akan memungkinkan tahanan untuk berintraksi dengan sesama tahanan dan staf penjara, membuat hubungan sosial mereka menjadi lebih baik, hal ini menunjukkan kualitas hidup yang membaik pula selama menjalani sisa masa tahanan di lapas (Van Ginneken et al., 2018)

Selain itu Azhima juga mengatakan bahwa semakin positif dukungan sosial maka semakin tinggi subjective well-being, demikian pula sebaliknya bahwa semakin negatif narapidana mempersepsi dukungan sosial maka semakin rendah subjective well-being (Azhima \& Indrawati, 2018). Selanjutnya penelitianmengatakan Interaksi diantara WBP pengguna Narkoba menunjukkan adanya rasa kebersamaan (sense of togetherness) dan rasa saling memiliki (sense of belongingness) yang berimplikasi pada sekuritas mereka selama berada di Lapas (Riskiyani, 2016). Beberapa penjelasan tersebut juga sesuai dengan hasil wawancara yang dilakukan kepada WBP I dan 2. Mereka mengatakan petugas yang ada di lapas rehabilitasi sangat peduli dengan seluruh tahanan. WBP 2 merasa para petugas (psikolog, konselor dan dokter) menganggap mereka seperti anak, selalu membantu jika ada masalah. WBP 1 mengatakan petugas yang ada dilayanan rehabilitasi sering memberikan motivasi untuk mereka selama menjalani sisa masa tahanan sehingga merasa nyaman ketika mengikuti program rehabilitasi.Sedangkan pada aspek hubungan dengan lingkungan dan kesehatan fisik tidak memiliki pengaruh terhadap kualitas hidup WBP yang mengikuti layanan rehabilitasi di Lapas Narkotika Klas II A Jakarta.

\section{SIMPULAN}

Penelitian ini menghasilkan temuan bahwa terdapat tiga variabel (kesehatan psikologis, Kesehatan fisik dan hubungan sosial) berpengaruh positif terhadap kualitas hidup WBP yang mengikuti layanan rehabilitasi di Lapas Narkotika Klas IIA Jakarta. Ketiga variabel tersebut yaitu, kesehatan psikologis berpengaruh meningkatkan kualitas hidup sebesar 0.085, Kesehatan fisik sebesar 0,045, dan hubungan sosial sebesar 1,114. Faktor hubungan dengan lingkungan, kesehatan psikologis, hubungan sosial dan kesehatan fisik ternyata memberikan pengaruh sebesar 37,3 persen terhadap kualitas hidup WBP yang mengikuti layanan rehabilitasi di Lapas Narkotika Klas II A Jakarta. Hasil dari wawancara dengan dua orang WBP bahwa dalam layanan rehabilitasi yang meliputi aspek petugas (SDM), progam dan sarana prasarana, secara keseluruhan berpengaruh terhadap kualitas hidup yang lebih baik dibanding sebelum mengikuti layanan rehabilitasi. Namun masih dirasakan kurang dari aspek petugas layanan yaitu konselor, dimana konselor memiliki peran yang sangat penting dalam proses pemulihan WBP dari masalah narkotika.

Uji statistik membuktikan bahwa masih ada faktor lain yang dapat memengaruhi kualitas hidup WBP yang mengikuti layanan rehabilitasi di Lapas Narkotika Klas II A Jakarta yang belum diungkapkan dalam penelitian ini dengan presentase sumbangan pengaruh sebesar 62,7 persen. Perlu dilakukan penelitian lanjutan untuk mengetahui faktor selain kesehatan psikologis dan 
Putri Herdriani dan Palupi Lindiasari Samputra, Pengaruh Layanan Rehabilitasi Narkotika terhadap Kualitas Hidup Warga

hubungan sosial yang mempengaruhi kualitas hidup WBP yang mengikuti layanan rehabilitasi dilapas.

\section{DAFTAR PUSTAKA \\ Buku}

BNN. (2017). Peraturan Badan Narkotika Nasional Nomor 24 Tahun 2017 tentang Standar Pelayanan Rehabilitasi bagi Pecandu Narkotika dan Korban Penyalahgunaan Narkotika. BNN.

Direktorat Perawatan Kesehatan dan Rehabilitasi Kemenkumham. (2018). Petunjuk Pelaksanaan Layanan Rehabilitasi Narkotika Bagi Tahanan dan WBP di UPT Pemasyarakatan.

Kemenkumham. (2017). Peraturan Menteri Hukum dan HAM Nomor 12 Tahun 2017 tentang Penyelenggaraan Layanan Rehabilitasi Narkotika Bagi Tahanan dan Warga Binaan Pemasyarakatan Tahun 2017. Kemenkumham.

Lopez, S. J., \& C. R. Snyder, P. . (2003). Positive Psychological Assessment a Handbook of Models \& measures.Washington. American Psychological Association.

\section{Jurnal}

Azhima, D. D., \& Indrawati, E. S. (2018). Hubungan Antara Dukungan Sosial Keluarga Dengan Subjective Well-Being Pada Narapidana Perempuan Di Lembaga Pemasyarakatan. Empati, 7(2), 308-313.

Barquín, J., Cano, M. Á., \& Calvo, M. de los Á. (2019). Treatment, Reintegration, and Quality of Prison Life: Perception by Inmates. International Journal of Offender Therapy and Comparative Criminology, 63(13), 2291-2317. https://doi.org/10.1177/0306624X19851669

Janca, A. (1998). World Health Organization Measuring Quality of Life. In American Journal of Psychiatry (Vol. 155, Issue 2, pp. 1-10).

Laratmase, A. J. (2016). Pengembangan Alat Ukur Kualitas Hidup Nelayan. Jurnal Ilmiah Pendidikan Lingkungan Dan Pembangunan, 17(01), 34-41. https://doi.org/10.21009/plpb.171.04

Muller, A. E., \& Bukten, A. (2019). Measuring the quality of life of incarcerated individuals. International Journal of Prisoner Health, 15(1), 1-13. https://doi.org/10.1108/IJPH-02-2018-0005.

Pasareanu, A. R., Opsal, A., Vederhus, J. K., Kristensen, Ø., \& Clausen, T. (2015). Quality of life improved following in-patient substance use disorder treatment. Health and Quality of Life Outcomes, 13(1), 1-8. https://doi.org/10.1186/s12955-0150231-7

Prasetya, Aynal Mardiyah La Dupai, F. (2018). Studi kualitatif kualitas hidup mantan pecandu narkoba di klinik rehabilitasi BNN (Badan Narkotika Nasional) kota kendari tahun 2017. Jurnal Ilmiah
Mahasiswa Kesehatan Masyarakat, 3(1), 1-8.

Riskiyani, S. (2016). Perlakuan di Lapas , Interaksi Sosial dan Harapan Pengguna Narkoba Mantan Narapidana. Etnosia, 01(01), 71-84.

Van Ginneken, E. F. J. C., Palmen, H., Bosma, A. Q., Nieuwbeerta, P., \& Berghuis, M. L. (2018). The Life in Custody Study: the quality of prison life in Dutch prison regimes. Journal of Criminological Research, Policy and Practice, 4(4), 253-268. https://doi.org/10.1108/JCRPP-07-2018-0020.

Yulianti, M., \& Putri, M. A. S. (2015). Kualitas Hidup pada Narapidana di Lembaga Pemasyarakatan Klas Iia Wanita Tangerang. Jurnal Ilmu Ekonomi Dan Sosial, 4(1), 67-71. https://www.neliti.com/publications/237516/kualit as-hidup-pada-narapidana-di-lembagapemasyarakatan-klas-iia-wanitatangera\%0Ahttp://files/1025/Yulianti and Putri 2015 - Kualitas Hidup pada Narapidana di Lembaga Pemasyar.pdf.

\section{Prosiding}

Anggarwati, S., \& Nawangsih, E. (2016). Prosiding Psikologi Pengaruh Pelayanan Komprehensif Terhadap Quality of Life pada Pengguna NAPZA di LSM Rehabilitasi Rumah Cemara Bandung Berdasarkan WHOQOL-BREF. Psikologi, 2, 535540.

\section{Thesis}

Wijayanti, R. D. (2019). Analisis Pengaruh Tahapan Perubahan Perilaku dan Faktor Motivasi Klien Terhadap Penyelesaian Program Rehabilitasi Rawat Jalan Sesua Kebutuhan Klien Di Klinik $I P W L$ Lingkup BNN. Universitas Indonesia.

\section{Data dari Internet}

Ditjenpas. (2020). Sistem Database Pemasyarakatan. http://smslap.ditjenpas.go.id/public/krl/current/mo nthly/year/2019/month/12. 